Article

\title{
Land Ownership, Rent-Seeking, and Rural Gentrification: Reconstructing Villages for Sustainable Urbanization in China
}

\author{
Jinkun Yang ${ }^{1}$, Eddie C. M. Hui ${ }^{2}$, Wei Lang ${ }^{1, *}{ }^{\mathbb{C}}$ and ${\mathrm{Xun} \mathrm{Li}^{1, *}}^{1,}$ \\ 1 Department of Urban and Regional Planning, School of Geography and Planning, Sun Yat-sen University, \\ Guangzhou 510275, China; yangjk5@mail2.sysu.edu.cn \\ 2 Department of Building and Real Estate, The Hong Kong Polytechnic University, Hong Kong SAR 00852, \\ China; eddie.hui@polyu.edu.hk \\ * Correspondence: langw3@mail.sysu.edu.cn (W.L.); lixun@mail.sysu.edu.cn (X.L.)
}

Received: 9 May 2018; Accepted: 5 June 2018; Published: 13 June 2018

\begin{abstract}
Gentrification is a widespread urban phenomenon across the post-industrial world. However, rural gentrification has been explored insufficiently in the context of China's unprecedented urbanization. By reviewing the redevelopment processes in Zengcuoan village, Xiamen City, China, this study empirically reveals that the socio-spatial transformation of this village has been mainly led by artists and villagers based on institutional arrangements of land ownership. Rural gentrification, which involves refurbishing houses and public spaces, has played a key role in social life and the engagement between indigenous villagers and artists. As active rent-seekers, indigenous villagers contribute to gentrification in a combined effect with China's rural land property rights. Contrary to Western findings, villagers in China act as landlords who benefit from rural gentrification, which in turn causes grassroots artists or young people to move out because of the increasing rent or property prices. This paper attempted to enrich the extant understanding of rural Chinese gentrification and broaden the analytics of gentrification studies of the institutional arrangements from a land-ownership perspective. Contributing to the literature on rural gentrification, this study highlights the excessive commercialization of rent-seeking as the trigger of gentrification.
\end{abstract}

Keywords: rural gentrification; land ownership; village; rent-seekers; sustainable urbanization

\section{Introduction}

Gentrification is an inherently complex spatial phenomenon that involves changing economic, demographic, social, physical, and cultural landscapes. The effects of gentrification have expanded from world cities to local and small cities in both the Global North and Global South. In the 1960s, Glass first introduced the concept of gentrification, which is a renovation process of deteriorated urban neighborhoods by influx of more affluent residents. This concept is used to explain the gradual decline in decaying urban working-class communities as middle-class people move into the neighborhoods, which leads to a series of changes in population, society, culture, and material landscapes [1-4]. In addition, the diffusion of the effects of gentrification has generally occurred in Western countries, expanding from urban to rural areas, which is termed rural gentrification. Gentrification represents an emerging research agenda. The notions of gentrification circulating in urban studies are distinct from the dominant interpretation in rural studies in four different aspects: (1) a manifestation of the uneven circulation of capital; (2) a strategy to reduce reproductive labor; (3) a strategy to buy into particular lifestyles; and (4) a contradictory and complex group of contextually specific processes. These four aspects were identified to demonstrate the differences between the study of urban and rural gentrification $[2,3,5,6]$. 
As both a process and a concept, the spatial diffusion of gentrification creates considerable possibilities for comparative research on this phenomenon $[7,8]$. In the context of globalization and neoliberalism, China is experiencing continuous rapid urbanization and complex urban-rural transformation. In peri-urban villages, gentrification has started to occur with the arrival of the urban middle class, artists, tourists, business professionals, and various other social groups, which has prompted the repair and renovation of villagers' houses for commercial use. Thus, the function of the original villages has been transformed from residential to commercial in the urban-rural community redevelopment process.

Early studies on Western gentrification investigated the process of changing neighborhoods. For example, low-income residents left the neighborhoods, and young urban professionals ("yuppies") entered and replaced the original residents [9-11]. Previous studies explored the secondary role that the government plays in urban gentrification, by not only generating but also influencing the overall gentrification process [12-14]. According to some experts, gentrification has increasingly experienced strong local government intervention, which has led to "state-led gentrification" [15-17]. Most scholars believe that gentrification causes a serious injustice and an inequitable separation between the highly privileged and underprivileged people in cities $[15,18,19]$. Lee [17] argued that the major beneficiaries of the gentrification process are local governments and private developers instead of the existing residents.

With the development of counter-urbanization in developed countries, rural gentrification has occurred in rural communities around metropolitan areas. Rural gentrification has been described as "counter-urbanization" or "amenity migration", and in sociology and geography, studies have applied the notion of rural gentrification that is not the replacement of but the co-existence of renters, meaning residents alongside villagers [20]. The concept of rural gentrification was first proposed by Parson in a study on the class composition of rural residents in the United Kingdom [5]. Rural gentrification refers to a transition process through which the middle class moves to rural settlements for greater comfort and more leisure space, which changes the economic, population, and socio-cultural structure of the rural communities [6]. After the reconstruction of new spaces in villages, marginal price changes are experienced by the immobile residents in or near the villages [21].

The existing literature has extensively discussed the evolution process and characteristics of rural gentrification, such as exploring the land rent gaps [22-24], rural space reconstruction [25,26], mechanisms of rural gentrification [27,28], and the experience economy [20,29]. According to Phillips [30], gentrification is necessarily associated with home owners acting as capitalist developers, or the emergent service class being questioned, and the possibility of "marginal gentrifiers" being raised. Reinvestment in rural land is not intended to repair the decaying material landscape but to fully use the original natural environment to realize the middle-class pursuit of a beautiful natural environment. In contrast, the production of environmental and rural living space is used to maximize the rent of rural land $[20,22,30]$. The original rural development model, based on local agriculture and mining production, has been replaced by the consumerist economy with the transformation of urban development and institutional changes [31].

Rural gentrification in China has seldom been explored in academic research in terms of cultural, economic, and physical refurbishment of villages. During China's fast urbanization process, villages experience negative social externalities and disamenity, which are essential to planning and policy-making when reconstructing village spaces [32]. China's urban renewal or redevelopment of informal settlements has faced various constraints such as limited investment and ambiguous property rights [33]. China's unprecedented urbanization has been dominated by urban expansion mode since the 1980s. The "new-type urbanization 2014" has practically and potentially required the government and professionals to undertake new development in already built-up land, promote urban regeneration, and redevelop villages, marking a new era of urbanization in China [34]. However, less attention has been paid to the role of indigenous villagers and grassroots artists in rural gentrification under the dual land ownership structure. 
The present study provides evidence on the effects of rural gentrification in reconstruction and redevelopment of China's villages. Studies have investigated various aspects of China's village redevelopment [35], many of which focused on the evolution process in rural gentrification [6,7], but few examined the joint bottom-up effect of artists and villagers in driving rural gentrification from a property rights perspective. This paper attempts to enrich the extant understanding of rural gentrification in the Chinese context and broaden the analytics used in gentrification studies from the perspective of institutional arrangements for land ownership. In the past, rural gentrification mainly occurred through the transformation of villages where the establishment of new commercial housing was accompanied by the entry of a large number of groups of "gentry", but was less promoted by artists and young entrepreneurs, indigenous villagers, and others. This type of rural gentrification indicates a transformation from the original top-down government-led gentrification changes to a bottom-up artist- and villager-promoted gentrification. The purpose of this study was to explore rural gentrification and its driving forces in China by probing into the socio-spatial transformation processes in Zengcuoan village, Xiamen City, China.

This paper is based on a fieldwork project conducted in Zengcuoan village from October 2013 to July 2017, through the administration of 20 field surveys. During this period, we primarily obtained first-hand information through in-person interviews. First, in-depth interviews were conducted with 15 grassroots artists (e.g., Alei's Dream Traveler Inn, Antelope Inn, Mark Inn, etc.) and 11 local villagers (village representatives, Mr. Ji, Mr. Zeng, etc.). The team was divided into eight groups to interview grassroots artists, villagers, and tourists through interviews. Questions during the interviews focused on three issues: (1) the local social, economic, and demographic structures in Zengcuoan; (2) economic relationships between artists and villagers in terms of housing provision and changes in house rent prices; and (3) the role of various social actors in Zengcuoan's socio-spatial transformation. Additionally, the team communicated with a wider range of grassroots artists, indigenous villagers, and tourists in the process of field research to further understand and gain first-hand impressions of their emotional situation and habitual dwelling. On the whole, the fieldwork project helps us to obtain the first-hand information through in-depth interviews with grassroots artists and villagers in Zengcuoan village. Although the selected research objects are representative and typical, it takes a lot of time and staff to undertake in-depth interviews. In addition, the interviews are based on the individual observations of the researchers and the responses of specific groups cannot be considered as representative of all groups in the community.

This study investigates the trajectory of Zengcuoan's gentrification from the institutional arrangement perspective in Xiamen City, China. Specifically, this study attempts to seek the answer to the question: What are the driving forces of rural gentrification in the Chinese context? The findings imply that rural gentrification has been led by artists and indigenous villagers, and the latter are the active rent-seekers in the gentrification process. The village community has undergone a gentrification process in which original inhabitants are demanding high rental prices, which in turn causes the grassroots artists and youth to move out when rental rates become unaffordable. Rural gentrification, which involves refurbishing houses and public spaces, plays a key role in social life and in the engagement between indigenous villagers and artists. As active rent-seekers, indigenous villagers contribute to gentrification in a combined effect with China's rural land property rights. This study highlights the excessive commercialization of rent-seeking as the trigger for rural gentrification.

This paper first introduces studies on gentrification, briefly reviews the concept of rural gentrification, and explains the emergence and importance of rural gentrification issues in villages given China's fast urbanization. Section 2 interprets rural gentrification in China from an institutional perspective with particular consideration of land rent-seeking. To examine rural gentrification in practice, Section 3 provides a case study of Zengcuoan village's redevelopment. Section 4 analyzes the driving forces of rural gentrification based on the discussion on Zengcuoan village and highlights planning policy implications for future sustainable urbanization. Section 5 concludes this study. 


\section{Dual Land Ownership: Institutional Arrangements on Rural Gentrification in China}

Institutional details, policy implementation, and planning regulation have a strong effect on village redevelopment, thereby influencing rural gentrification. China has been experiencing fast and complex transformation, where various external and internal non-standard factors exert profound effects on urban space. China's urban spatial structure has undergone major transformations since the economic reform and opening up policy introduction in 1978. Marketization and globalization have led to the formation of new urban space in Chinese cities [36]. Changes in institutional models during the reform period resulted in the construction of complex urban spaces in Chinese cities. Coupled with accumulation of capital and advocacy of market-oriented development, Chinese cities started entering the post-industrial era to form an industrial structure dominated by the service economy. The built environment is experiencing a transition from industrialization to post-industrialization, where villages are transforming into cultural and creative villages in some metropolitan suburbs. The poor quality village environment is not well-suited to the urbanization of modern China. Village externalities, in the form of improved social and residential environments, are highly localized to the residents living in or near villages [4]. Postindustrial transition implies that villages shift from a space of production to a space of consumption. To this extent, rural gentrification can be considered as another form of capitalism expansion by reconstructing new space, changing village environments, and promoting tourism and real estate investment. Local villagers are changing their land and houses for reproduction by renting them out for residential or business use.

Land property rights significantly influence urbanization. In China, the land institutions include complete state-owned and incomplete rural collective land property rights. According to the country's constitution, land ownership is a form of socialist public ownership, which combines the property rights of state- and collective-owned land. Urban lands belong to the state, whereas rural lands are owned by the collective. This concept implies that China holds two different types of property bundles that complete the ownership of state-owned land in urban areas, whereas incomplete property collective land in rural areas includes the urban and rural land dual ownership structure [37,38]. Under the existing laws and regulations, redevelopment of villages must follow the land expropriation process, meaning collective-owned land must be transformed into state-owned before it can be released to the market [39].

The American economist Alonso [40] developed the land rent curve based on land use patterns in the "isolated state" and proposed a land rent curve under complete market competition. Forming a land rent curve results from the selection of various types of economic factors in the market given complete property rights conditions.

Due to the dualistic system of property rights in China, different benefits are received in the urban and rural environments. Urban land obtains value from property rights through property rights markets. Conversely, rural collective property rights cannot be exchanged directly in land markets. Their value has to be realized through further investment or production on the land, such as building or renting factory space. The potential profits under the dualistic structure of land property rights therefore becomes land rent surplus. Hence, the value of compensation is low as a new type of profit, i.e., land rent surplus, $\mathrm{ABCD}$, is produced through the interaction of these two types of property rights. During urban land expansion, to decrease the payments made to villagers within the Q1Q2 area and because collective land property rights limit property rights, the income from these property rights is not fixed, and the building quality is relatively low. Accordingly, collective-owned land rent is lower than that of surrounding urban land [38]. Those villages' land prices are lower than those of the surrounding urban land; thus, local governments can receive higher land revenue and real estate value premiums. Collective land owners cannot benefit directly through the land market, which can only benefit from the land market through government expropriation or requisition. Thus, rural collective land ownership is not a complete property right (Figure 1).

Institutional arrangements include a set of rules for specific actions and relationships, considering planning efficiency, fiscal and social equity, and service provisions [41,42]. As mentioned, urban lands 
belong to the state, whereas rural lands are owned by the collective. This dualistic system has resulted in the appearance of land rent surplus, which provides incentives for construction on rural land owned by rural collective institutions [38]. We argued that land rent surplus is derived from the dual property rights structure of China's land system. The villagers' houses are repaired and renovated for commercial use under land rent surplus. Loose land management and development control based on incomplete property provides opportunities for artists and villagers to jointly promote rural redevelopment. Based on the existing institutional framework, the villagers provide housing to collect housing rent, and the artists promote rural gentrification by opening cultural and creative shops to attract tourists.

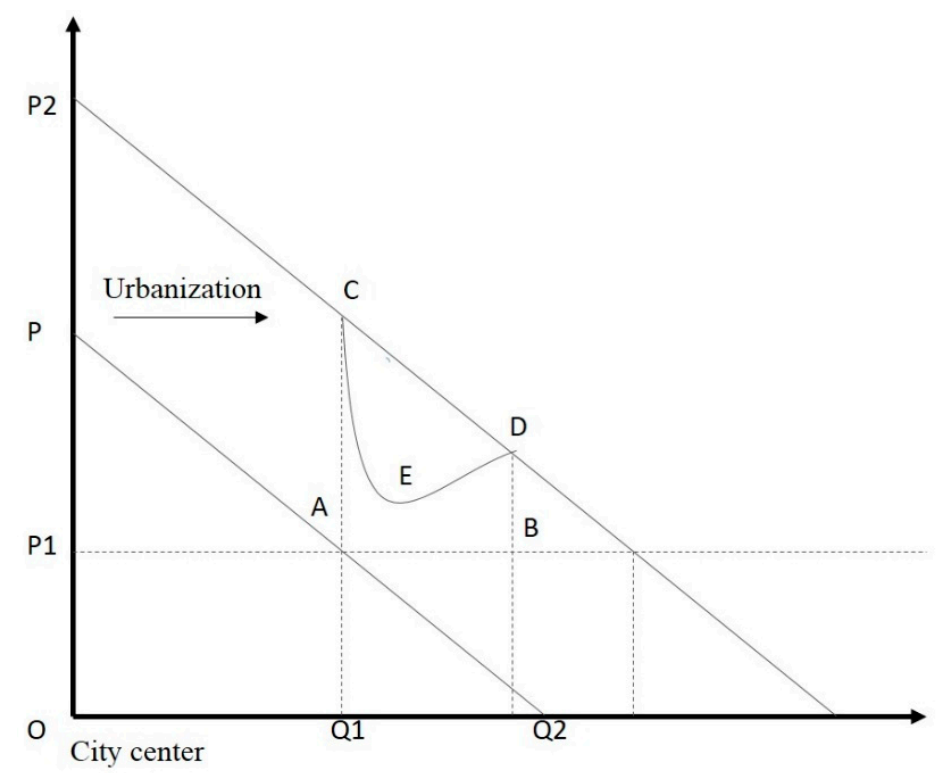

Figure 1. China's rural gentrification under land rent surplus. Source: authors adopted from Li et al. (2010: Figure 5) [38].

\section{A Case study of Zengcuoan, Xiamen City}

\subsection{Zengcuoan}

This section presents a case study where we outline some of the features that exemplify the village redevelopment experience and rural gentrification in China. The chosen case study village is Zengcuoan, located in the southeast of Xiamen Island, which belongs to the Siming district, Xiamen City, and Binhai subdistrict office, which is $15.5 \mathrm{~km}$ away from Xiamen airport and $6.8 \mathrm{~km}$ away from the Xiamen railway station in China (Figure 2). The village lies in the east of White Stone Turret and borders Huangcuo village, west of Hulishan Fort, south of Xiamen Huandao Road (also called Xiamen Circular Road), and north of the Yupin Mountains. By the seaside, the central area of Zengcuoan accounts for $0.33 \mathrm{~km}^{2}$ of the approximately $6.5 \mathrm{~km}^{2}$ administrative area.

In 2012, Zengcuoan was a little-known village in Xiamen City that was facing demolition. Ten years later, Zengcuoan became "China's most artistic fishing village". This extant native fishing village, which now hosts tens of thousands of tourists from all over the world each day, has become a gathering place for cultural and creative youth, with many successful entrepreneurial stories. The village is a combination of cultural creativity, commercialism, and entertainment. This traditional and simple small fishing village was completely reborn. Every year, tens of millions of tourists arrive and enrich the cultural progress of Xiamen City. Zengcuoan has been successfully transformed from a common village into an art and cultural village through reconstruction and redevelopment. The physical and socio-cultural spaces were reconstructed by the influx of social capital. 


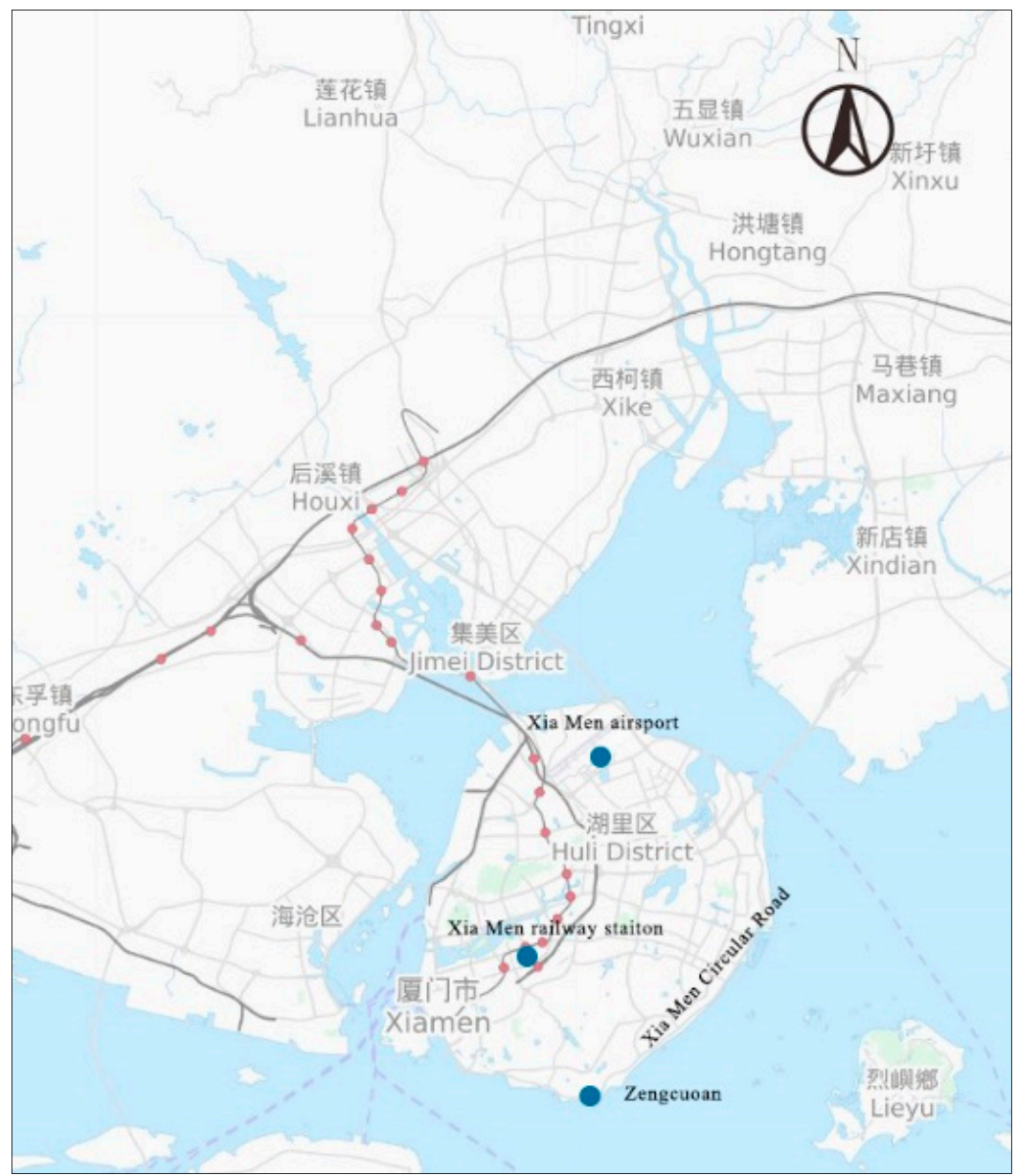

Figure 2. Location of Zengcuoan, Xiamen city, China. Source: Authors adopted the Baidu open map archived in 2017.

\subsection{Stage 1: Traditional Farming and Fishing Village Before the 1990s}

\subsubsection{Development}

Zengcuoan was a fishing village during the late Southern Song Dynasty. During the Ming Dynasty, the Zengcuoan community was named after the surname of the largest Zeng family in the village. After the economic reform and opening up policy introduction in 1978, several villagers went to work in Southeast Asia and donated money to improve their home village. Thus, Zengcuoan features good building construction quality compared with other villages, many of which comprise Western-style houses along the Xiamen Huandao Road. At the time, the neighborhood was located between urban and rural areas. Since 1980, various construction activities have been conducted in Zengcuoan village. In the 1980s, Zengcuoan and Gulangyu (also known as Kulangsu) island and the historic district of Zhongshan were designated as tourist areas. Zengcuoan preserved its original natural, traditional, and rural style. The exotic houses show potential for future development (Figure 3a).

\subsubsection{Initial Arrangement of Land Use under the Collective Land System}

Before the 1990s, Zengcuoan was mainly a residential area for villagers who were mostly fisherfolk. The industrial structure was relatively simple (Figure 4a, stage 1). The village generated land rent surplus as the government determined the land value under the principle of cost minimization based on the initial land title arrangement. During the urban expansion process, due to limited fiscal expenditure, the government had to expropriate rural land for new construction that provided 
the lowest land rent, or so-called land utilization compensation, to the rural collectives or villagers. Consequentially, the remaining areas of those villages, which were the villagers' homesteads, were left behind because they would increase the land rent cost, which would mean much higher compensation to the villagers, according to the legal rural land provision in China. We assumed that $R=A B C D$, where $\mathrm{R}$ refers to rent surplus of the remaining land for construction. As the property rights of collective land are incomplete property rights, land rent surplus is lower than that of state-owned land with clear property rights, that is, area E.

\subsection{Stage 2: From Ordinary Village to Oil Painting Village}

\subsubsection{Development}

In 1997, Zengcuoan traffic conditions improved due to the construction of the Xiamen Circular Road (Huandaolu), which strengthened its links with the surrounding areas. The scenery surrounding the fishing village and the characteristics of the village buildings attracted a large number of students and teachers from Xiamen University, Fuzhou University, and the Gulangyu Art Institute. Sculpting and painting studios moved to Zengcuoan, where a smaller population, larger space, and a relaxed environment were conducive to creative inspiration. Although Zengcuoan was once known as an "oil painting village", the rent increase during the latter stage of development caused the painting industry to relocate to low-rent neighborhoods.

At the same time, writers, well-known directors, filmmakers, and other groups of people came to live in the village. Construction of the software park attracted a group of white-collar tenants whose offices were located near Zengcuoan. As this population became active on the Internet, the village's visibility increased. In 2002, completion of Xiamen University's student apartments brought in a considerable number of students. The rent in this village compared with that in other regions was relatively lower; thus, the village attracted an increasing number of student residents. Development of village houses into inns promoted the improvement of commercial facilities and shops. Consequently, the village's commercial atmosphere gradually formed (Figure 3b).

\subsubsection{Land Use under the Collective Land Institution}

Construction of the Xiamen Circular Road, the main road right before the village, improved traffic conditions. Zengcuoan manifested scenic panorama as a fishing village during this period, attracting teachers and students from art colleges. Villagers created spare rooms for rent as working studios for college teachers and students. A village house originally used for living was commercialized to provide rooms for oil painting studios for college students. During that period, the main features of rural gentrification involved the creation of "oil painting villages" by the teachers and students and the provision of houses mainly for the creation of oil paintings [43].

With advancing urbanization, the value of state-owned land around Zengcuoan rose, generating positive externalities for collective land and encouraging rural collective property rights organizations to strengthen the development of non-agricultural industries. Internalization of state-owned land maximized internal access to land rent residual value. However, this residual value did not reach the level of urban land rent C1D1. Assuming that land rent surplus is R1, then R1 = A1B1C1D1. The construction of the Xiamen Circular Road improved traffic conditions. Thereafter, teachers and students from art colleges came to the village and ultimately transformed the location into an oil-painting area. These changes increased Zengcuoan land rent and resulted in R1 being greater than R (Figure 4b, Stage 2). 


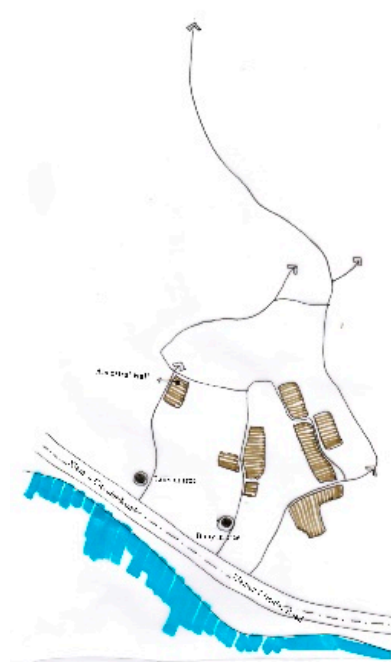

(a)

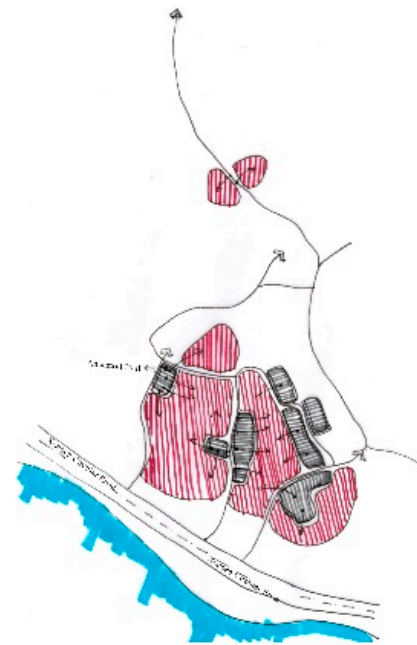

(b)

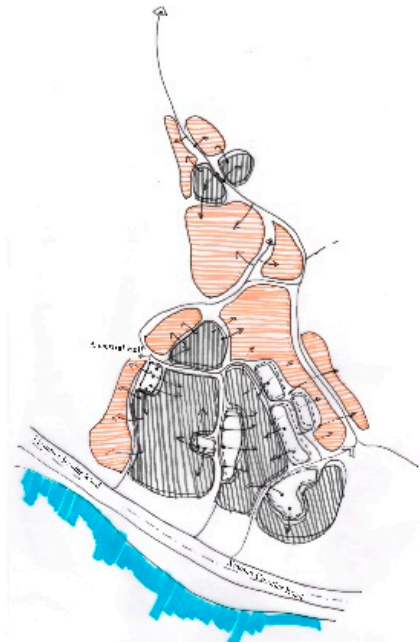

(c)

Figure 3. Spatial expansion of Zengcuoan village during the fast urbanization period. (a) Spatial pattern of traditional farming and fishing villages before the 1990s; (b) Spatial expansion of in 1997-2003; (c) Zengcuoan's further spatial expansion in 2004-2011. Source: drawn by the authors.

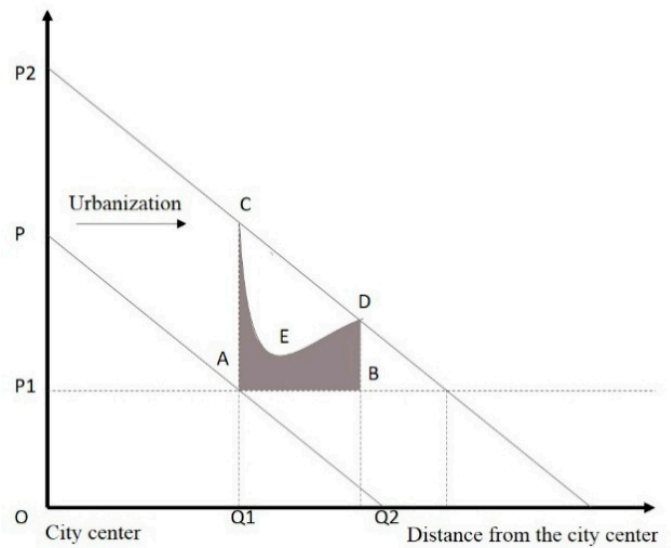

(a)

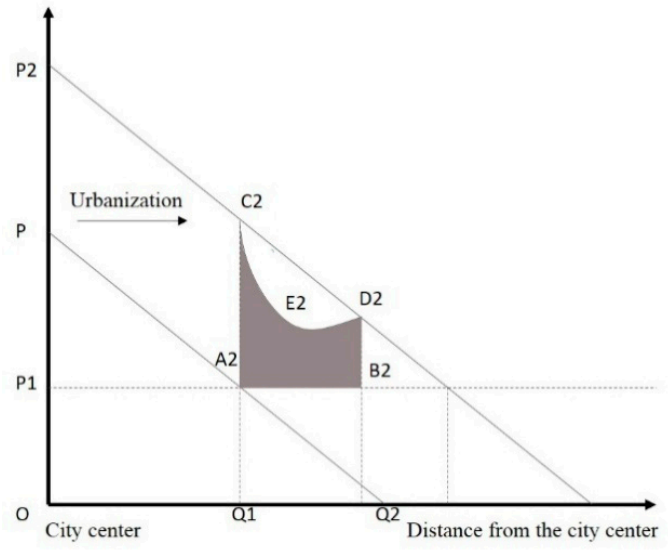

(c)

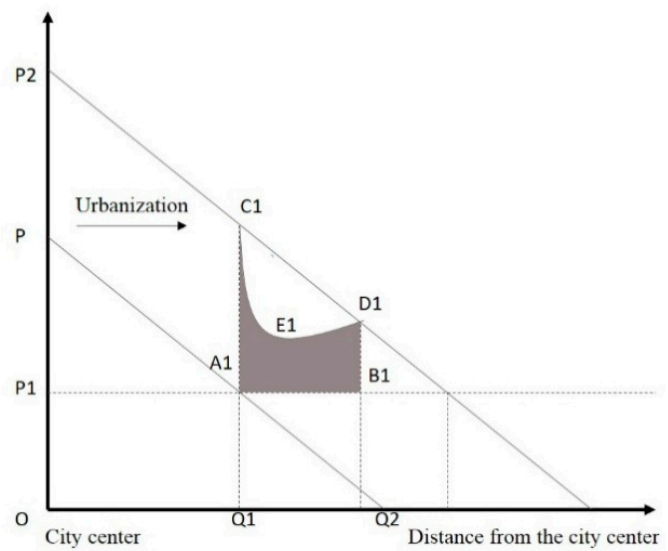

(b)

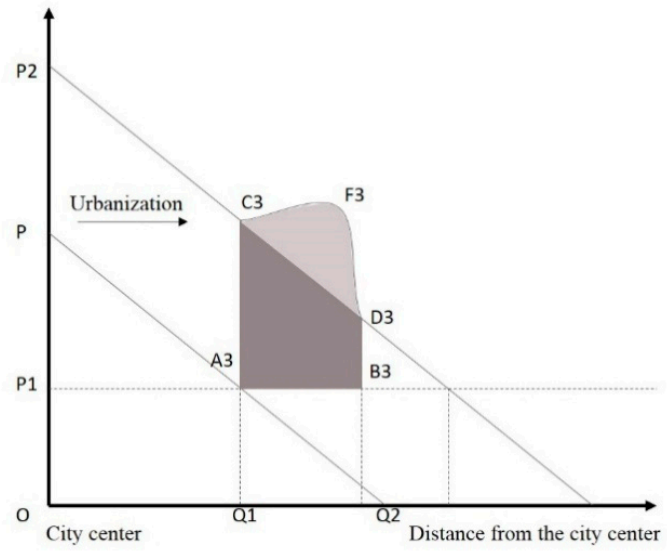

(d)

Figure 4. Rural gentrification under land rent surplus. (a) Stage 1: Development during the starting phase (before the 1990s); (b) Stage 2: Oil painting village (1997-2003); (c) Stage 3: Formation of cultural and creative village (2004-2011); (d) Stage 4: Prosperity and dilemma of cultural and creative village (2012-present). Source: authors adopted from Li et al. (2010: Figure 5). 


\subsection{Stage 3: From an Oil Painting Village to a Cultural and Creative Village}

\subsubsection{Development}

In 2004-2005, a considerable number of inns located in Zengcuoan offered cheaply priced rooms, such as Alei's Dream Traveler Inn, which attracted sight-seeing tourists because of the seaside view, nearby tourist spots, and beautiful natural environment. The family hotel rapidly developed owing to the shortage in accommodation during the holidays. Simultaneously, this increase in tourists gradually attracted several art shops such as See the Sunny, Three Years and Two Classes, and Black Shop. The government imposed strict rules on family hotels with regard to safety issues, such as fire protection. In the early days, only 20 or 30 family hotels and service shops in operation were evaluated favorably or had a positive reputation on the Internet through comments from visitors. The good reviews were received from the first group of young people who developed a fondness for new management concepts, as exemplified by the Three Years and Two Classes Shop. In 2010, the number of visitors rapidly increased due to the operation of high-speed railway stations in Xiamen. Although the government doubted the hotel business at the early stages, it became concerned with transforming and upgrading the rural economy afterward by using family hotels as an important driving force for the rural economy in an era of rapid economic and social development (Figure 3c).

\subsubsection{Land Use under the Collective Land Institution}

According to its Internet publicity, Zengcuoan is "facing the sea, with spring blossoms," which makes it attractive to artistic youth. Simultaneously, with the improvement in the external traffic conditions of Xiamen as a tourism center, a large number of tourists have flocked to the village. Tourists have contributed significantly to the rapid development of Zengcuoan family hotels, thereby contributing to the constant increase in land rent. As a result, the original oil painting studios can no longer afford the high rent and had to relocate. The studios have been replaced by family hotels that have developed vigorously. Village land value has increased further, and its performance is depicted as land rent R2, R2 = A2B2C2D2, R2 > R1 (Figure 4c, stage 3). This change was largely due to the improvement in Xiamen's overall traffic conditions, tourism service environment, the large number of tourists, and further urbanization. To maximize access to land rent surplus, cultural and creative industries and inns were constructed in Zengcuoan. However, along with oil painting studios, these structures were unable to bear the high cost of rent and were gradually replaced and relocated (Figure $4 \mathrm{~d}$ ).

\subsection{Stage 4: Prosperity and Plight of Transformation from 2012 to the Present}

\subsubsection{Development}

After more than 10 years of rapid transformation from a village to a mixed-function area (Figure 5), Zengcuoan was named "the most artistic fishing village in China" from the results of a public online evaluation. This evaluation helped Zengcuoan attract an increasing number of tourists. A significant correlation exists between public Internet attention and the number of visitor arrivals. Although network attention cannot represent the absolute number of actual visitors, it demonstrates the trend in changes in the quantity of online attention in accordance with passenger flow. The Zengcuoan network attention increased from 2011 to 2015 according to the Baidu Index. This index shows that, during the aforementioned period, the number of actual tourists grew annually as indicated by online attention to the village (Figure 6).

With the development of the tourism industry in Xiamen, an increasing number of tourists visited Zengcuoan. As a result, catering and other businesses grew rapidly. Thus, the value of land also increased. The wave of commercialization gradually resulted in prosperity. As the cultural and creative industries required a lengthy period of creation and production, short-term benefits were unremarkable. A number of businesses could no longer afford the rising pressure of rent and were 
forced to move out of Zengcuoan. The continuous surge in rent prices, driven by the interests of the villagers, gave way to illegal constructions that became popular at the time. The original pedestrian street scale was damaged, and the building of façades became chaotic. Public space was occupied and less land was left available (Figure 7). The deterioration highlighted the overall obstructed development due to the village's infrastructure development.

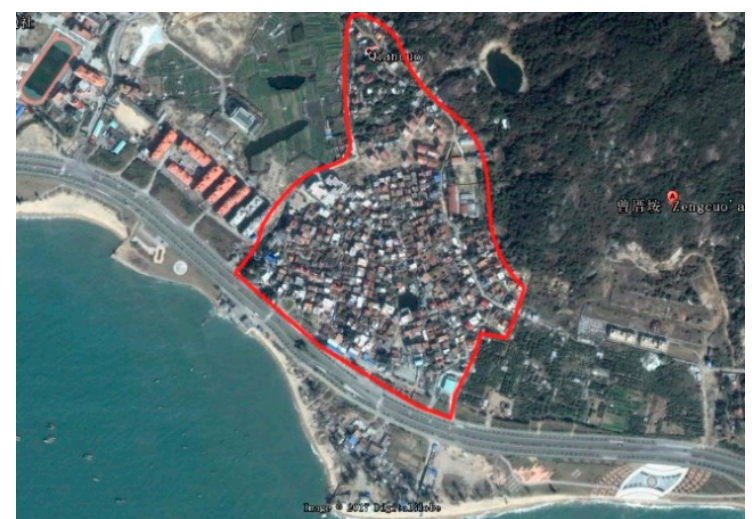

(a)

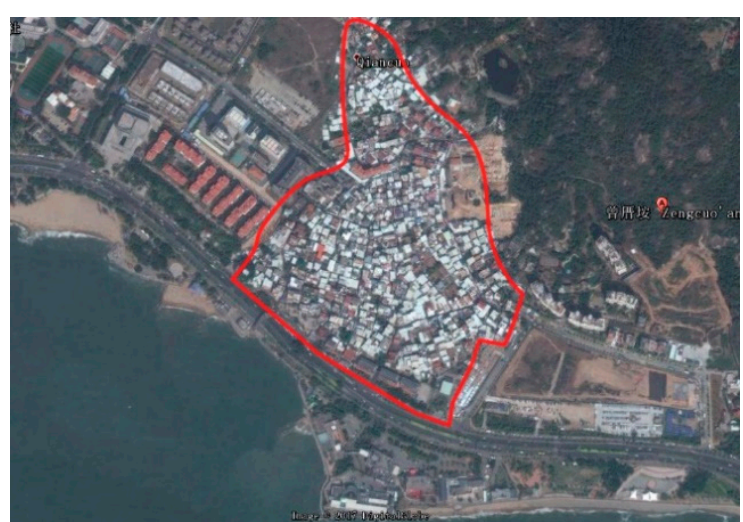

(b)

Figure 5. Study area in Zengcuoan in 2003 and 2017. (a) The study area in 2003; (b) The 2017 Zengcuoan google map. Source: Archived from Google Earth Map, 2003 and 2017.

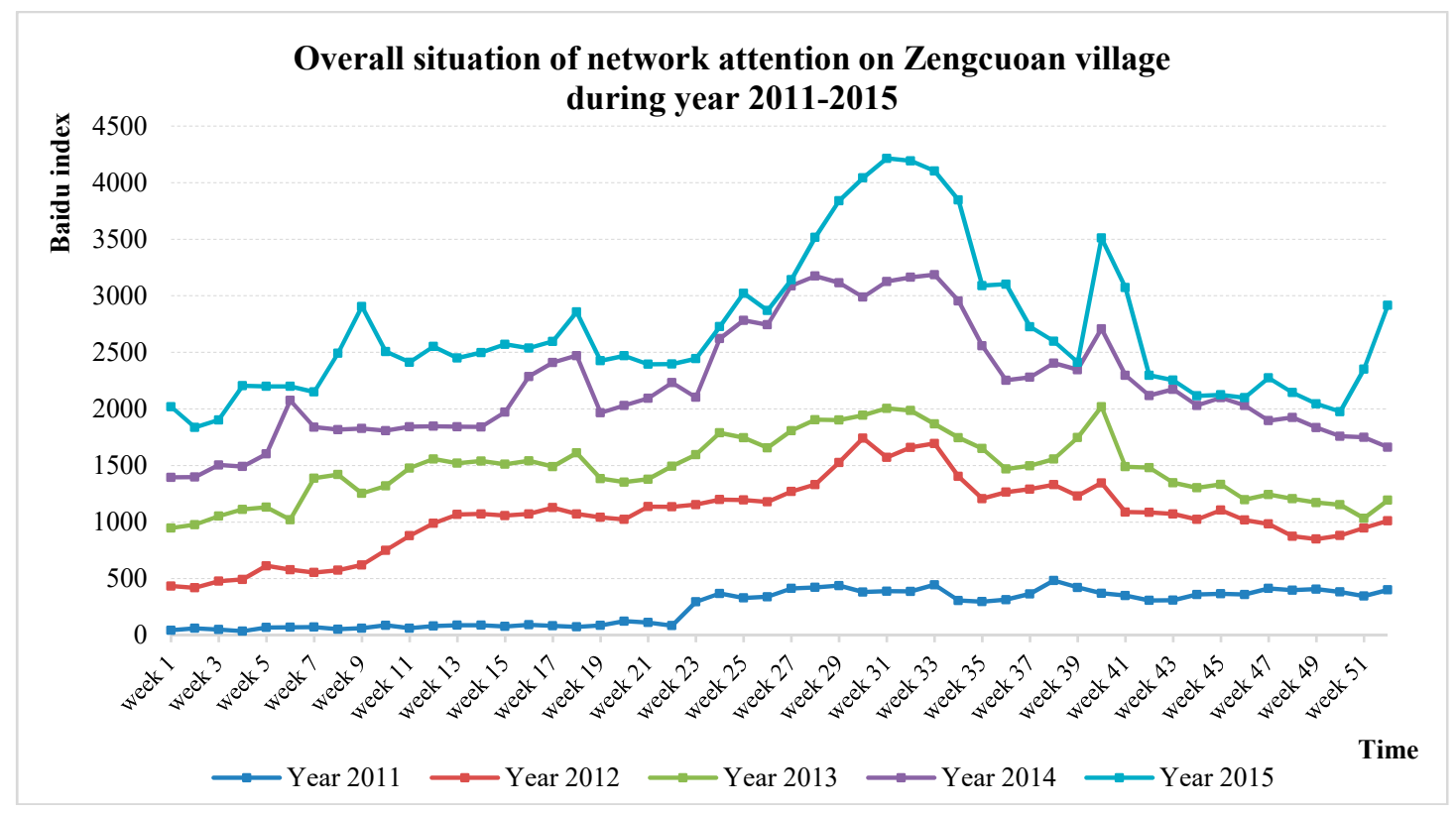

Figure 6. Internet attention directed toward Zengcuoan in 2011-2015. Source: drawn by the author.

During the years of rapid development, Zengcuoan gained a reputation as a "Chinese art village" that combines cultural creativity, music, accommodation, and catering. As of 2018, the village is popular among tourists, especially young ones. The externally manifested challenges that continually result in increased land rent include: (1) Villagers' pursuit of the value from rent is becoming serious, causing a wave of illegal construction and destroying the originally comfortable streets in the village; (2) Excessive commercialization is eroding the original artistic atmosphere, causing the unsustainable development of the existing path and the subsequent decline of the village; (3) Chaotic internal traffic influences the experience of tourists. A good environment should guarantee the sustainable income of the villagers from rent and maintain the sustainable development of the area. 


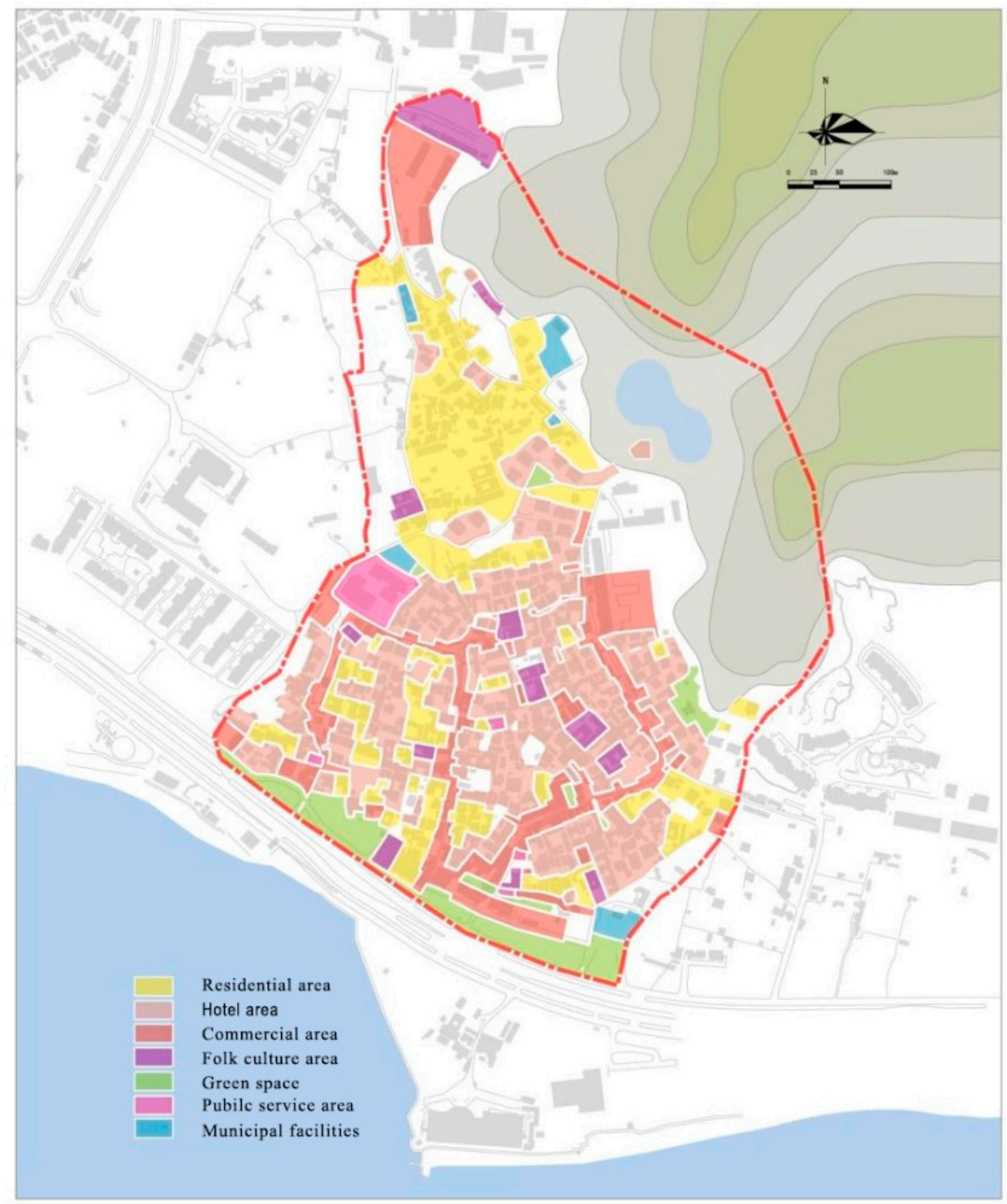

Figure 7. Land use map of Zengcuoan (2012-present). Source: drawn by the author.

\subsubsection{Land Use under Collective Land Institution}

During this period, the value of land rose with the increasing number of tourists. The collective land was basically occupied by the village homesteads. With the increase in rent, the villagers privately built extra floors and occupied public spaces. Inns dominated the village when a large number of cultural and creative shops failed to pay the rent and were relocated outside the neighborhood. Zengcuoan attracted tourists who provided substantial income for the villagers. In turn, the village developed at a remarkable pace. At the same time, its development became a distinctive and traditional representation of the government's hotspot project. However, management difficulties emerged, including a lack of public service facilities, lag in management institution, or negative externalities in the development. The fundamental source of urgency, survival in the wave of future tourism competition, and reshaping the atmosphere of culture and art must be solved in accordance with the crossroad stage of development.

Given the continually rising land value, this period of land rent surplus is denoted R3. When R3 = A3B3C3D3, then R3 > R2, in which the external increase in land rent surplus indicates a higher price than that of the neighboring state-owned land. As cultural and creative industries 
require long periods to gain remarkable profits, businesses are experiencing increasing difficulty in bearing the rising pressure caused by rent prices that have forced cultural and creative industries to move out of Zengcuoan. Thus, the houses have been occupied by commercial establishments, such as stores and restaurants, thereby causing land rent to increase continually. The government possesses inadequate external driving force for the village transformation because the high cost of negotiating and maintaining collective property rights has resulted in the loss of efficiency. Although external transformation was lacking, the villagers and vendors showed eagerness to improve the physical environment to enhance the quality of life and create good business spaces. Thus, internal self-renewal was possible (Figure $3 \mathrm{~d}$, stage 4). When the rent of village homestead is compared with that of the surrounding real estate prices (Figure 8), the rent curve is similar to that in Figure 4, stage 4.

The village management system causes confusion because the city's regulations and planning institution are inapplicable to Zengcuoan. The hidden social problems and other negative externalities increase the challenges for the transformation of Zengcuoan. The villagers obtain land rent surplus by pursuing maximum benefits, thereby resulting in illegal construction, such as when an originally pleasant street scale was obliterated by the occupation of public space to build additional room spaces. Due to the effect of high rent, only commercial shops can succeed rapidly. Furthermore, the crowd shifted from artists and artistic youth to tourists. Overall, Zengcuoan displayed the following order of succession: ordinary fishing village to oil painting village to cultural and creative village.

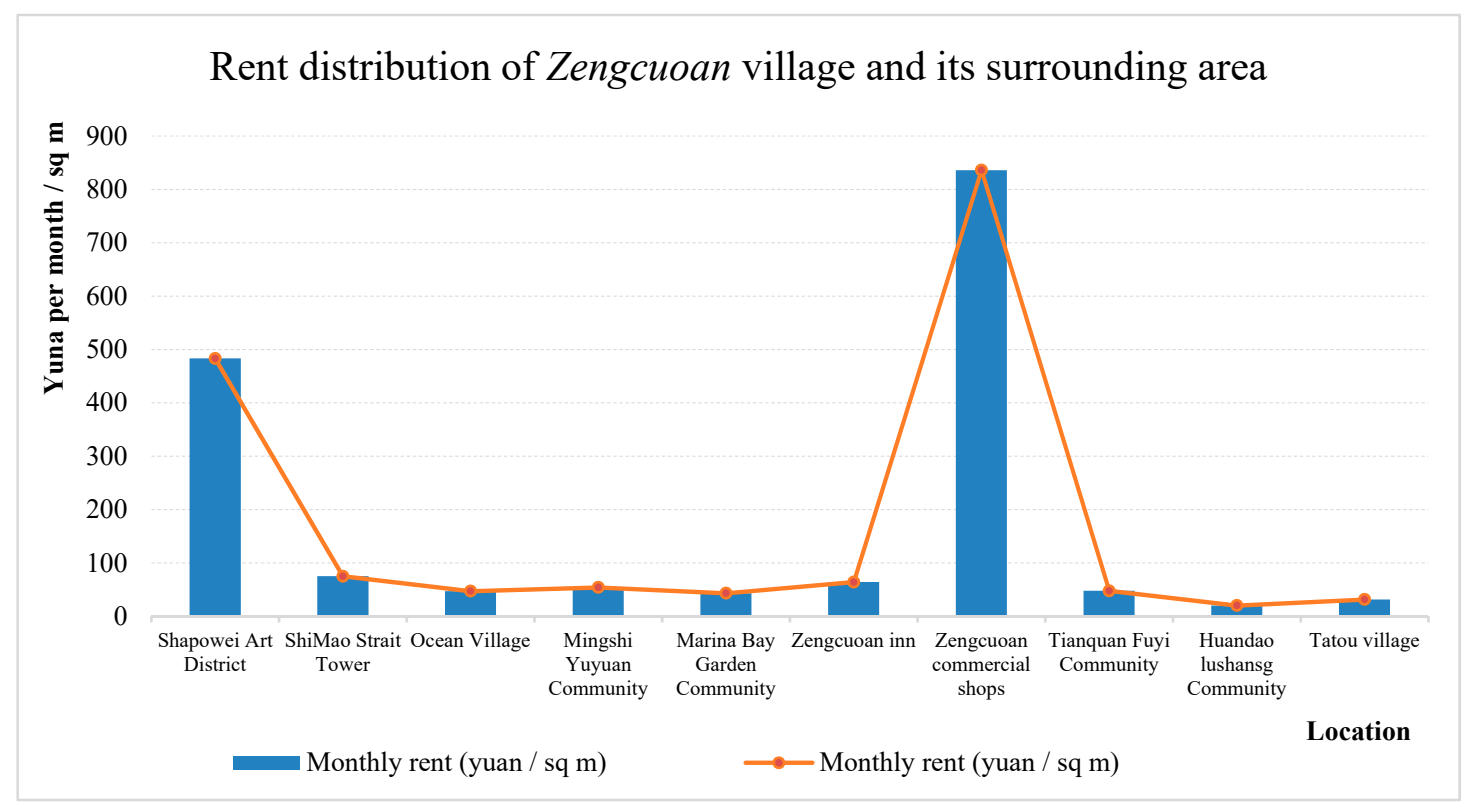

Figure 8. Rent distribution of Zengcuoan and its surrounding areas. Source: drawn by the author.

\section{Institutional Analysis: Rent-Seeking Behavior and Rural Gentrification}

\subsection{Dualistic and Fragmented Land Ownership}

Under the dual land use regulation in China, the city consists of two parts: urban areas (state land ownership) and villages (collective land ownership). The development of villages results from land requisition under incomplete property rights during urbanization, and the villagers can only benefit from building additional informal property on collective land. This has led to low levels of infrastructure construction, disorder, and crowded living conditions [44]. The system of dual property rights in China created the coexistence of dual land use regulation during the transition period from a planned to a market economy since the 1980s. 
The incomplete and ambiguous delineation of property rights of rural collective land, along with changes in the institutional model and capital accumulation during the transformation, has resulted in the complexity of Chinese urban spaces. Extensive informal behavior and rent-seeking activities among various interest groups has resulted in informal spaces for an informal economy. With regard to ambiguous property rights, the market benefit is always transferred to the investors or land owners who maximize land or housing property profit. In rural gentrification, the reconstruction of rural space, as residents pursuing a sense of belonging and community, results in the increase in property prices that triggers new investment and speculation, thereby creating an interconnected loop. The increasing demand for housing has triggered significant price increases in real estate, which has important consequences. The ambiguous property rights of village collectives are also responsible for poor housing quality. Given the property rights of collective land ownership, the government has less control of village development. The transformation from original homesteads to shops and hotels was maintained based on original property rights.

\subsection{Loose Land Management and Development Control}

State-owned land is under formal management and urban development control, whereas the village land management system is loose and lacks a defined institution. In rural areas, land is allocated to households according to the number of families. Since 1989, numerous areas have stopped housing allocation because of insufficient land. This condition inevitably leads to high-level land development to maximize rent and use of space. Although specific new house spaces are legally located in restricted rural housing areas (ceiling to standard per farmer housing is $240-280 \mathrm{~m}^{2}$ ), land development rights are subject to the ease of control. The ease of standard institutional environment serves as the basis for the continuous renewal of Zengcuoan, including the transformation from an oil painting village to a hotel location and a cultural and creative area. Given the ongoing commercialization, illegal construction, and occupancy of numerous public spaces, the village committees and various organizations, in their autonomy, have played important roles in reconstructing this village. Local organizations have cooperated with the government to develop inns and manage illegal construction, where the top-down and bottom-up collaborative governance emerged under diverse institutions, such as the environmental management institution and public force-based village institution.

\subsection{Rent-Seeking Behavior of Diversified Actors under the Institutional Framework}

During the Zengcuoan gentrification process, capital is bound by the government and social forces to support cultural development and improve daily living spaces. The government encourages the development of tourism, introducing businesses and maintaining village development by improving infrastructure, shop, and hotel management institutions and village culture construction, and implementing other positive means. However, capital has become an important force that maintains the protection and development of Zengcuoan in the modern market economy. Traditional cultures are preserved by transferring rental housing rights and balancing the economic benefit. Artists are identified as owners in leasing relationships and become legitimate users of the new space. The varied use of spaces driven by different values had led to continuous replacement and evolution, which in turn has led to the formation of new spaces.

New spaces promote the village's continuous evolution. In the pursuit of maximized interests, roadways, public spaces, and other public places were eroded by commercial activities and buildings. The villagers destroyed the original pleasant street scale through illegal construction to maximize their benefits, and they continually break business contracts and increase the rent given rental interest. Short-term gains are remarkable due to the long periods of creation of cultural and creative industries. Consequently, young people cannot afford to pay the rent, and therefore decide to leave Zengcuoan. However, a large amount of capital has flowed into the village to maximize profits. Catering businesses have continually expanded, promoting a continuous change in the village economy. Therefore, planning and policymaking should not only ensure a healthy and safe environment but also guarantee 
affordable property and prevent the displacement of low-income tenants by placing a rent price cap to ensure sustainable village reconstruction.

Infrastructure investments that promote urban expansion and produce land rent surplus results in rural gentrification. Zengcuoan has gradually developed into China's most artistic fishing village through social forces that integrate professional planners, community organizations, and residents. This village renewal considered the interests of the public and the government. The government's infrastructure investment and institutional construction promoted the renewal and transformation according to the village's preferences and market demand. The overall environment improved by providing additional public toilets and using fire hydrants to enhance sanitary and public services, and other facilities such as the Xiamen Music Square, Little Egret Art Center, painting square, and fishing bridges, which contribute to a continued increase in the rental rates (Figure 9).

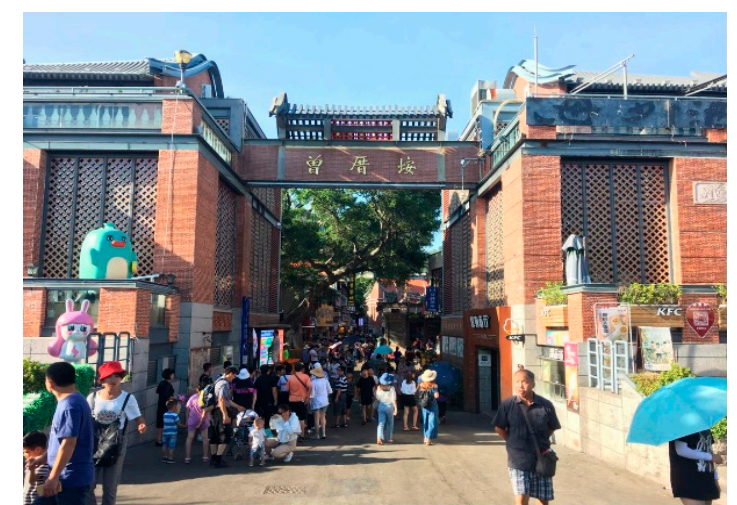

(a)

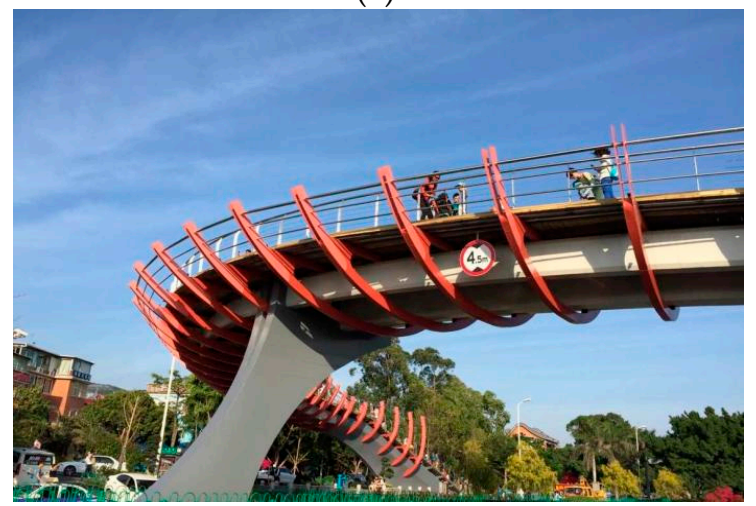

(c)

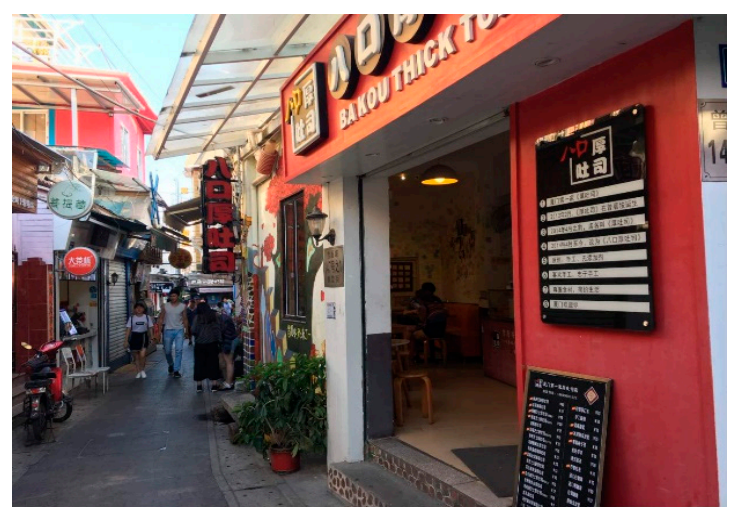

(b)

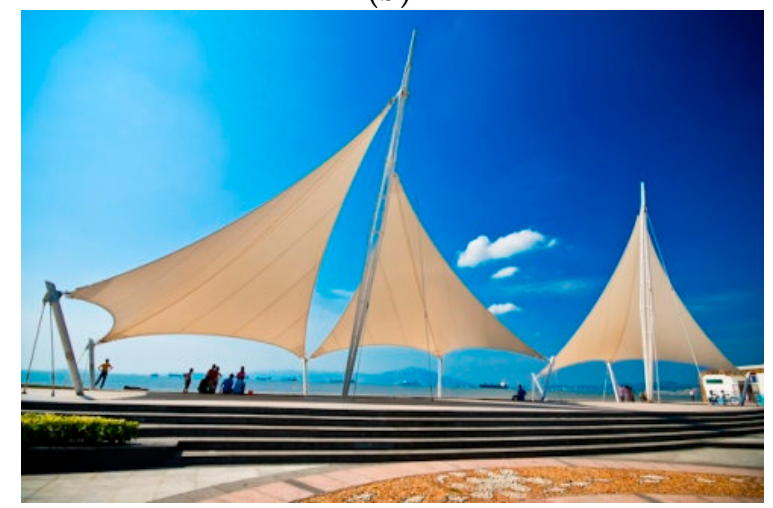

(d)

Figure 9. Image of improved and newly built facilities in Zengcuoan. (a) Zengcuoan entrance; (b) Commercial street in Zengcuoan; (c) Fishing bridge connecting Zengcuoan to the seaside; (d) Xiamen Music Square along the coastal area in front of Zengcuoan. Source: Authors' survey.

The case of Zengcuoan shows that cities should not allow social injustice when the development situation is unique, requiring a change in the planning paradigm for China's sustainable village reconstruction. Specifically, the government should consider setting a rental ceiling to prevent pricing out low-income residents or creative artists by balancing the landlords' financial benefit and the tenants' ability to pay. To help reduce gentrification and avoid displacement of low-income residents, the government could consider only allowing rental rather than the sale of the reconstructed villages. Planning regulation may benefit from economic incentives to reconstruct and revitalize villages, where the development process involves planning the layout of streets, maintaining open spaces and services, and upgrading infrastructure. 


\section{Conclusions}

In the context of globalization and neoliberalism, China is experiencing continuous rapid urbanization and complex rural-urban transformation. This study empirically examined the socio-spatial transformation processes in Zengcuoan village to explore principles of the sustainable reconstruction of village space and improve our understanding of rural gentrification from the property rights perspective. Rural gentrification plays a key role in the engagement between indigenous villagers and artists. Indigenous villagers, being the active rent-seekers, contribute to gentrification through a combined effect with China's rural land property rights. The villagers' houses were transformed for commercial use under land rent surplus. Loose land management and development control, based on incomplete property, has provided opportunities for both artists and villagers to promote rural redevelopment. Based on the existing institutional framework, the villagers provide housing spaces to earn rent, and the artists promote rural gentrification by opening cultural and creative shops to attract tourists. In general, the institutional policy is an important foundation for the development of rural gentrification, and market power is an important driving force based on the existing institutional framework.

Throughout China's urbanization process, compared with counter-urbanization in developed countries, artists and villagers play an essential role in rural gentrification. The example of Zengcuoan shows how an ordinary fishing village can be gradually upgraded from an oil-painting location to a landmark area. Zengcuoan has undergone two phases: transformation from a traditional fishing to an oil painting village, and transformation from an oil painting to a cultural and creative village. Gentrification has had clear effects on village development, ownership structure demographics, and interactions between income and expense in villages. Local villagers obtain significant benefits due to China's rural land property rights system, which is different from that of Western countries. At the same time, the side effect of continuously higher rent for village properties has led to unaffordability for many residents. Thus, rural gentrification has forced a large number of grassroots artists to move away. The external effects on housing rent prices in villages has created socioeconomic changes in these villages.

We attempted to enrich the understanding of rural gentrification in China and broaden the analytics of gentrification studies from the institutional arrangement perspective of land ownership. In the past, rural gentrification mainly occurred through the transformation of villages where the establishment of new commercial housing was accompanied by the entry of a large number of groups of gentry, but was promoted to a lesser extent by artists, young people, and indigenous villagers. The discussion on the special roles of indigenous villagers and artists based on institutional arrangements in Xiamen's socio-spatial transformation has the potential to add a new dimension to the explanation of rural gentrification. China is experiencing continuous rapid urbanization and complex urban-rural transformation. From the socio-spatial transformation of Zengcuoan, we examined the joint effect of the artists and villagers from the bottom up in driving rural gentrification from the property rights perspective. Indigenous villagers in China as landlords benefit from rural gentrification by profiting from housing rental income and providing community services. Although over-commercialization has led to increased rental prices, which caused grassroots artists and youth to leave, the artists and youth can earn income by operating cultural creative shops and hotels during the socio-spatial transformation. Rural gentrification is believed to be spontaneous beyond the state-led model, which has important reference value for rural development in China in the new era. Overall, this paper explains the perplexing socio-spatial transformation of the village and indigenous villagers in China, as landlords benefit from rural gentrification, which in turn causes the grassroots artists and youth to move out when rental rates become unaffordable. Contributing to the literature on rural gentrification, this study highlights the excessive commercialization of rent-seeking as the trigger of gentrification. The conclusions can serve as a reference for rural development in China's new wave of urbanization. 
Author Contributions: Conceptualization, J.Y. and X.L.; Investigation, J.Y. and W.L.; Writing-Original Draft Preparation, J.Y.; Writing-Review \& Editing, E.C.M.H. and W.L.; Supervision, X.L. and E.C.M.H.; Funding Acquisition, X.L.

Funding: This research was funded by [The Fundamental Research Funds for the Central Universities in China] grant number [17lgy39]; [National Natural Science Foundation of China] grant number [41271138, 41571118].

Conflicts of Interest: The authors declare no conflict of interest. The founding sponsors had no role in the design of the study; in the collection, analyses, or interpretation of data; in the writing of the manuscript, and in the decision to publish the results.

\section{References}

1. Van Criekingen, M.; Atkinson, R.; Bridge, G. (Eds.) Gentrification in a global context. The new urban colonialism. London and New York. Hous. Soc. Ser. 2005, 4, 518.

2. Smith, N. New globalism, new urbanism: Gentrification as global urban strategy. Antipode 2002, 34, 427-450. [CrossRef]

3. Phillips, M. Rural gentrification and the processes of class colonisation. J. Rural Stud. 1993, 9, $123-140$. [CrossRef]

4. Wu, W.; Wang, J. Gentrification effects of China's urban village renewals. Urban Stud. 2017, 54, $214-229$. [CrossRef]

5. Parsons, D. Rural Gentrification: The Influence of Rural Settlement Planning Policies; University of Sussex: Brighton, UK, 1980; Volume 3.

6. González, A.P. Heritage and rural gentrification in Spain: The case of Santiago Millas. Int. J. Herit. Stud. 2017, 23, 125-140. [CrossRef]

7. Smith, N. Blind man's buff, or Hamnett's philosophical individualism in search of gentrification. Trans. Inst. Br. Geogr. 1992, 17, 110-115. [CrossRef]

8. Phillips, M.; Smith, D.P. Comparative ruralism and 'opening new windows' on gentrification. Dialogues Hum. Geogr. 2018, 8, 51-58. [CrossRef] [PubMed]

9. Marcuse, P. Abandonment, Gentrification, and Displacement: The Linkages in New York City. In Gentrification of the City; Routledge: London, UK, 2013; pp. 169-193.

10. Ley, D. Alternative explanations for inner-city gentrification: A Canadian assessment. Ann. Assoc. Am. Geogr. 1986, 76, 521-535. [CrossRef]

11. Hackworth, J. Postrecession Gentrification in New York City. Urban Aff. Rev. 2016, 37, 815-843. [CrossRef]

12. Bailey, N.; Douglas, R. Housing renewal, urban policy and gentrification. Urban Stud. 1997, 34, 561-578. [CrossRef]

13. Badcock, B. Thirty years on: Gentrification and class changeover in Adelaide's inner suburbs, $1966-1996$. Urban Stud. 2001, 38, 1559-1572.

14. Smith, N. Toward a theory of gentrification a back to the city movement by capital, not people. J. Am. Plan. Assoc. 1979, 45, 538-548. [CrossRef]

15. Uitermark, J.; Willem, J.D.; Reinout, K. Gentrification as a governmental strategy: Social control and social cohesion in Hoogvliet, Rotterdam. Environ. Plan. A 2007, 39, 125-141. [CrossRef]

16. Wyly, K.E.; Daniel, J.H. Gentrification, segregation, and discrimination in the American urban system. Environ. Plan. A 2004, 36, 1215-1241. [CrossRef]

17. Newman, K.; Philip, A. Neoliberal urban policy and new paths of neighborhood change in the American inner city. Environ. Plan. A 2004, 36, 1151-1172. [CrossRef]

18. Walks, A.; Martine, A. The factors inhibiting gentrification in areas with little non-market housing: Policy lessons from the Toronto experience. Urban Stud. 2008, 45, 2594-2625. [CrossRef]

19. Lees, L.; David, L. Introduction to special issue on gentrification and public policy. Urban Stud. 2008, 45, 2379-2384. [CrossRef]

20. Hines, J.D. Rural gentrification as permanent tourism: The creation of the 'New'West Archipelago as postindustrial cultural space. Environ. Plan. D Soc. Space 2010, 28, 509-525. [CrossRef]

21. Palmquist, R. Valuing localized externalities. J. Urban Econ. 1992, 31, 59-68. [CrossRef]

22. Darling, E. The city in the country: Wilderness gentrification and the rent gap. Environ. Plan. 2005, 37, 1015-1032. [CrossRef]

23. Smith, N. Gentrification and the rent gap. Ann. Assoc. Am. Geogr. 1987, 77, 462-465. [CrossRef] 
24. Phillips, M. Making space for rural gentrification. In Proceedings of 2nd Anglo-Spanish Symposium on Rural Geography; Hernando, F., Ed.; University of Valladolid: Valladolid, Spain, 2001.

25. Phillips, M. Differential productions of rural gentrification: Illustrations from North and South Norfolk. Geoforum 2005, 36, 477-494. [CrossRef]

26. Smith, D.P.; Phillips, M. Comparative approaches to gentrification: Lessons from the rural. Dialogues Hum. Geogr. 2018, 8, 3-25.

27. Hamnett, C. The blind men and the elephant: The explanation of gentrification. Trans. Inst. Br. Geogr. 1991, 16, 173-189. [CrossRef]

28. Woods, M. Engaging the global countryside: Globalization, hybridity and the reconstitution of rural place. Prog. Hum. Geogr. 2007, 31, 485-507. [CrossRef]

29. Smith, D.P.; Debbie, A.P. Socio-cultural representations of greentrified Pennine rurality. J. Rural Stud. 2001, 17, 457-469. [CrossRef]

30. Phillips, M. Other geographies of gentrification. Prog. Hum. Geogr. 2004, 28.1, 5-30. [CrossRef]

31. Cloke, P.; Jo, L. The Rural State? Limits to Planning in Rural Society; Clarendon Press/Oxford University Press: Oxford, UK, 1990.

32. Song, Y.; Zenou, Y. Urban villages and housing values in China. Reg. Sci. Urban Econ. 2012, 42, 495-505. [CrossRef]

33. Chen, H.; Tao, W. The revival and restructuring of a traditional folk festival: Cultural landscape and memory in Guangzhou, South China. Sustainability 2017, 9, 1767. [CrossRef]

34. Lang, W.; Chen, T.; Li, X. A new style of urbanization in China: Transformation of urban rural communities. Habitat Int. 2016, 55, 1-9. [CrossRef]

35. He, S.; Qian, J.; Xu, Y.; Liu, B. Spatial-temporal evolution of rural gentrification amidst rapid urbanization: A case study of Xiaozhou Village, Guangzhou. Acta Geogr. Sin. 2012, 67, 1044-1056.

36. Wu, F.; Laurence, J.C.; Ma, Z.J. Transformation and Reconstruction: Chinese Urban Development Multidimensional Perspective; Southeast University Press: Nanjing, China, 2007.

37. Li, X.; Xu, X. Study on the Micro-mechanism of the Evolution of Villages in the Transitional Period. Urban Reg. Plan. Res. 2008, 1, 55-69.

38. Li, X.; Xu, X.; Li, Z. Land property rights and urbanization in China. China Rev. 2010, 10, 11-37.

39. Lin, G. The redevelopment of China's construction land: Practising land property rights in cities through renewals. China Q. 2015, 224, 865-887. [CrossRef]

40. Alonso, W. Location and Land Use; Harvard University Press: Cambridge, MA, USA, 1964.

41. Arch, A.F. Sustainable urban renewal: The tel aviv dilemma. Sustainability 2014, 6, 2527-2537. [CrossRef]

42. Zheng, S.; Kahn, M.E. Land and residential property markets in a booming economy: New evidence from Beijing. J. Urban Econ. 2008, 63, 743-757. [CrossRef]

43. Wang, M.; Li, X. Urban and Rural Planning Reform: Good Environment and Harmonious Society to Create; China Construction Industry Press: Beijing, China, 2016.

44. Wang, Y.P.; Wang, Y.; Wu, J. Urbanization and informal development in China: Urban villages in Shenzhen. Int. J. Urban Reg. Res. 2009, 33, 957-973. [CrossRef]

(C) 2018 by the authors. Licensee MDPI, Basel, Switzerland. This article is an open access article distributed under the terms and conditions of the Creative Commons Attribution (CC BY) license (http:/ / creativecommons.org/licenses/by/4.0/). 